\title{
Pentingnya Memahami Konsep Dasar Keselamatan dan Kesehatan Kerja (K3) untuk Menghindari Risiko dan Hazard dalam Pemberian Asuhan Keperawatan
}

\author{
Novi Pratiwi \\ novipratiwi211@gmail.com
}

\begin{abstract}
Abstrak
Rumah sakit merupakan institusi pelayanan kesehatan yang ternyata di samping dapat menghasilkan dampak positif berupa pelayanan kesehatan yang baik terhadap pasien, juga dapat menimbulkan dampak negatif berupa pengaruh buruk kepada manusia seperti pencemaran lingkungan, sumber penularan penyakit dan menghambat proses penyembuhan dan pemulihan penderita. Keselamatan dan kesehatan kerja (K3) adalah salah satu bentuk upaya untuk menciptakan tempat kerja yang aman, sehat, bebas dari pencemaran lingkungan, sehingga dapat melindungi dan bebas dari kecelakaan kerja, pada akhirnya dapat meningkatkan efisiensi dan produktivitas kerja. Maka untuk menghindari terjadinya risiko dan bahaya dalam pemberian asuhan keperawatan di rumah sakit, perawat perlu memahami konsep dasar keselamatan dan kesehatan kerja di rumah sakit. Tujuan dari penulisan ini adalah untuk mengetahui tentang pentingnya memahami konsep dasar keselamatan dan kesehatan kerja untuk menghindari risiko dan hazard atau bahaya dalam pemberian asuhan keperawatan di rumah sakit
\end{abstract}

Kata kunci : Keselamatan dan kesehatan kerja, risiko, bahaya..

\section{Latar Belakang}

Rumah sakit merupakan institusi pelayanan kesehatan yang didalamnya terdapat bangunan, peralatan, manusia (petugas, pasien dan pengunjung) dan kegiatan pelayanan kesehatan yang ternyata di samping dapat menghasilkan dampak positif berupa pelayanan kesehatan yang baik terhadap pasien, juga dapat menimbulkan dampak negatif berupa pengaruh buruk kepada manusia seperti pencemaran lingkungan, sumber penularan penyakit dan menghambat proses penyembuhan dan pemulihan penderita.

Selain potensi bahaya berupa penyakit infeksi yang umumnya berasal dari pasien, rumah sakit juga mempunyai potensi bahaya lain yang mempengaruhi situasi dan kondisi di rumah sakit yaitu peledakan, kebakaran, kecelakaan yang berhubungan dengan instalasi listrik, radiasi, bahan-bahan kimia berbahaya, gas anestesi, gangguan psikososial, dan ergonomi. 
Dalam meningkatkan upaya tindakan pencegahan risiko dan bahaya dalam pemberian asuhan keperawatan di rumah sakit, diperlukan pengetahuan dan sikap perawat dalam menerapkan keselamatan dan kesehatan kerja agar terhindar dari risiko penularan penyakit baik dari sesama pasien maupun dari pasien ke perawat karena perawat mempunyai risiko yang tinggi untuk menerima pajanan penyakit akibat adanya infeksi yang dapat mengancam keselamatannya saat berkerja.

Keselamatan dan kesehatan kerja (K3) adalah salah satu bentuk upaya untuk menciptakan tempat kerja yang aman, sehat, bebas dari pencemaran lingkungan, sehingga dapat melindungi dan bebas dari kecelakaan kerja, pada akhirnya dapat meningkatkan efisiensi dan produktivitas kerja. Kecelakaan kerja tidak saja menimbulkan korban jiwa tetapi juga kerugian materi bagi pekerja dan pengusaha, tetapi dapat mengganggu proses produksi secara menyeluruh, merusak lingkungan yang pada akhirnya akan berdampak pada masyarakat luas.

Keberhasilan program Keselamatan dan Kesehatan Kerja (K3) di rumah sakit tidak lepas dari sikap kepatuhan personal baik dari pihak perawat maupun pihak manajemen atas dalam melaksanaan peraturan dan kebijakan peraturan K3 untuk mendukung pencapaian zero accident di rumah sakit. Dalam melaksanakan setiap program Keselamatan dan Kesehatan Kerja tersebut, para pekerja rumah sakit mempunyai risiko untuk terjadinya Penyakit Akibat Kerja (PAK) dan Kecelakaan Akibat Kerja (KAK). Hal ini disebabkan karena Penyakit Akibat Kerja (PAK) merupakan penyakit yang disebabkan oleh pekerjaan, alat kerja, bahan, proses maupun lingkungan kerja.

Maka untuk menghindari terjadinya risiko dan bahaya dalam pemberian asuhan keperawatan di rumah sakit, perawat perlu memahami konsep dasar keselamatan dan kesehatan kerja di rumah sakit. Konsep dasar Keselamatan dan Kesehatan Kerja Rumah Sakit (K3RS) adalah upaya terpadu seluruh pekerja rumah sakit, pasien, pengunjung/pengantar orang sakit untuk menciptakan lingkungan kerja, tempat kerja rumah sakit yang sehat, aman dan nyaman baik bagi pekerja rumah sakit, pasien, pengunjung/pengantar orang sakit maupun bagi masyarakat dan lingkungan sekitar rumah sakit.

\section{Metode}

Metode yang dilakukan dalam penulisan ini adalah metode kepustakaan yaitu dengan melakukan peninjauan, mengumpulkan data-data dan menganalisisnya yang diperoleh dari buku, e-book, jurnal-jurnal terkini ataupun sumber informasi lainnya yang memuat informasi pembahasan tentang pentingnya memahami konsep dasar Keselamatan dan Kesehatan Kerja (K3) untuk menghindari risiko dan hazard dalam pemberian asuhan keperawatan. Pengolahan 
data dilakukan mulai dari menganalisis isi buku dan jurnal atau sumber informasi lainnya yang berhubungan dengan pentingnya memahami konsep dasar Keselamatan dan Kesehatan Kerja (K3) untuk menghindari risiko dan hazard dalam pemberian asuhan keperawatan hingga kesimpulan dari penulis.

\section{Hasil}

Keselamatan dan Kesehatan Kerja (K3) merupakan suatu upaya perlindungan kepada tenaga kerja dan orang lain yang memasuki tempat kerja terhadap risiko dan bahaya dari akibat kecelakaan kerja. WHO mencatat Tahun 2004 kasus infeksi nosokomial didunia berupa penularan hepatitis B sebayak 66.000 kasus, hepatitis C sebanyak 16.000 dan 10.000 kasus penularan HIV. Hal ini tidak menutup kemungkinan bagi petugas kesehatan dapat terinfeksi. Telah diperkirakan terjadi penularan hepatitis B (39\%), hepatitis C (40\%), dan HIV (5\%) pada tenaga kesehatan diseluruh dunia.

Menurut Maja (2009) dalam Precautions used by occupational health nursing students during clinical plancements menjelaskan terkait penerapan APD. Penelitian ini menunjukan tingginya tingkatan penerapan mencuci tangan, penggunaan APD dan tingkat pelatihan yang lebih dari $80 \%$ responden. Selain itu, penelitian ini juga menjelaskan bahwa 17,8\% respondennya gagal menggunakan APD ketika praktek akibat terbatasnya jumlah APD yang disediakan di tempat praktek. Selain itu juga menjelaskan bahwa sikap negatif yang ditunjukan dengan menolak menggunakan APD karena merasa tidak nyaman mendorong responnya untuk berperilaku tidak menggunakan APD.

Sedangkan penelitian Habni (2009) yang berjudul Perilaku Perawat dalam Pencegahan Infeksi Nosokomial di Rumah Sakit Umum Pusat Haji Adam Malik Medan dalam hal pencegahan infeksi nosokomial yang melibatkan perawat di ruang rawat inap, IGD, ICU, dan rawat jalan sebagai responden. Hasil penelitiannya didapatkan $76 \%$ perawat yang tidak mendapatkan pelatihan tentang pencegahan infeksi nosokomial cenderung memiliki perilaku yang buruk dalam melakukan pencegahan infeksi nosokomial.

Pengetahuan perawat mengenai pencegahan infeksi dengan melakukan tindakan septik dan aseptik serta kemampuan untuk mencegah transmisi infeksi di rumah sakit adalah tindakan pertama dalam pemberian pelayanan yang bermutu. Hal ini dapat diupayakan melalui peningkatan sikap perawat tentang kesadaran menggunakan APD dalam melakukan setiap tindakan keperawatan. Mengingat fungsi APD memiliki peran yang penting dalam upaya mengeliminir transmisi agent penyakit infeksi baik dari lingkungan rumah sakit, dari pasien ke perawat maupun dari pasien ke pasien lainnya atau infeksi yang terjadi pada pasien itu sendiri. 
Untuk dapat menggunakan APD secara benar harus didukung oleh pengetahuan dan sikap yang baik, dari segi pengetahuan perawat harus bisa memahami potensi risiko bahaya infeksi dan pintu masuk dari transmisi agent infeksi tersebut sehingga dapat memilih jenis dan bahan APD yang sesuai dengan potensi bahaya yang ada. Sedangkan dari segi sikap perawat harus didukung dengan perilaku yang baik terkait dengan penggunaan APD seperti kepatuhan dalam menggunakan APD dengan benar pada saat melakukan tindakan keperawatan dan kesadaran untuk merawat APD untuk menghindari terjadinya risiko dan bahaya di rumah sakit.

\section{Pembahasan}

Keselamatan dan kesehatan kerja merupakan suatu pemikiran dan upaya untuk menjamin keutuhan dan kesempurnaan baik jasmani maupun rohani tenaga kerja pada khususnya dan manusia pada umumnya, hasil karya dan budayanya menuju masyarakat makmur dan sejahtera. Sedangkan pengertian secara keilmuan adalah suatu ilmu pengetahuan dan penerapannya dalam usaha mencegah kemungkinan terjadinya kecelakaan dan penyakit akibat kerja. Dengan keselamatan dan kesehatan kerja maka para pihak tenaga kerja diharapkan dapat melakukan pekerjaan dengan aman dan nyaman serta mencapai ketahanan fisik, daya kerja, dan tingkat kesehatan yang tinggi.

\section{Keselamatan Kerja}

Keselamatan kerja adalah keselamatan yang bertalian dengan mesin, pesawat, alat kerja, bahan, dan proses pengolahannya, landasan tempat kerja dan lingkungannya serta cara-cara melakukan pekerjaan. Keselamatan kerja memiliki sifat yaitu sasarannya adalah lingkungan kerja dan bersifat teknik.

\section{Kesehatan Kerja}

Sehat digambarkan sebagai suatu kondisi fisik, mental dan sosial seseorang yang tidak saja bebas dari penyakit atau gangguan kesehatan melainkan juga menunjukkan kemampuan untuk berinteraksi dengan lingkungan dan pekerjaannya. Perhatian utama di bidang kesehatan lebih ditujukan ke arah pencegahan terhadap kemungkinan timbulnya penyakit serta pemeliharaan kesehatan seoptimal mungkin.

Status kesehatan seseorang menurut Blum (1981) ditentukan oleh empat faktor yaitu:

- Lingkungan, berupa lingkungan fisik (alami, buatan), kimia (organik/anorganik, logam berat, debu), biologik (virus, bakteri, mikroorganisme), dan sosial budaya (ekonomi, pendidikan, pekerjaan).

- Perilaku yang meliputi sikap, kebiasaan, tingkah laku. 
- Pelayanan kesehatan: promotif, perawatan, pengobatan, pencegahan kecacatan, rehabilitasi.

- Genetik, yang merupakan faktor bawaan setiap manusia.

Kesehatan kerja adalah spesialisasi dalam ilmu kesehatan/kedokteran beserta praktiknya yang bertujuan agar pekerja/masyarakat pekerja memperoleh derajat kesehatan yang setinggi-tingginya, baik fisik atau mental, maupun sosial dengan usaha-usaha preventif dan kuratif terhadap penyakit-penyakit/gangguan-gangguan kesehatan yang diakibatkan faktorfaktor pekerjaan dan lingkungan kerja, serta terhadap penyakit-penyakit umum. Kesehatan kerja memiliki sifat yaitu sasarannya adalah manusia dan bersifat medis.

Rumah sakit merupakan suatu industri jasa yang padat karya, padat pakar, padat modal dan padat teknologi sehingga risiko terjadinya Penyakit Akibat Kerja (PAK) dan Kecelakaan Akibat Kerja (KAK) sangat tinggi, oleh karena itu upaya K3 sudah menjadi suatu keharusan. Sasaran keselamatan dan kesehatan kerja (K3) di rumah sakit yaitu pengelola dan karyawan rumah sakit. Sedangkan tujuan keselamatan dan kesehatan kerja di rumah sakit yaitu terciptanya lingkungan kerja yang aman, sehat dan produktif untuk pekerja, aman dan sehat bagi pasien, pengunjung, masyarakat dan lingkungan sekitar rumah sakit sehingga proses pelayanan rumah sakit berjalan baik dan lancar.

Adapun tujuan khusus keselamatan dan kesehatan kerja di rumah sakit sebagai berikut.

1. Terwujudnya organisasi kerja yang menunjang tercapainya K3 di Rumah Sakit (K3RS).

2. Meningkatnya profesionalisme dalam hal K3 bagi manajemen, pelaksana dan pendukung program.

3. Terlindunginya pekerja dan mencegah terjadinya PAK dan KAK

4. Terselenggaranya program K3 di rumah sakit (K3RS) secara optimal dan menyeluruh.

5. Peningkatan mutu, citra, dan produktivitas rumah sakit.

Seorang perawat perlu memahami dan menerapkan konsep dasar keselamatan dan kesehatan kerja untuk menghindari terjadinya risiko dan hazard atau bahaya dalam pemberian asuhan keperawatan di rumah sakit. Risiko adalah kemungkinan kecelakaan akan terjadi dan dapat mengakibatkan kerusakan, sedangkan hazard atau bahaya adalah sesuatu yang berpotensi menyebabkan cedera atau luka.

Kecelakaan merupakan sebuah kejadian tak terduga yang dapat menyebabkan cedera atau kerusakan. Kecelakaan dapat terjadi akibat kelalaian dari perusahaan, pekerja, maupun keduanya, dan akibat yang ditimbulkan dapat memunculkan trauma bagi kedua pihak. Bagi pekerja, cedera akibat kecelakaan dapat berpengaruh terhadap kehidupan pribadi, kehidupan 
keluarga, dan kualitas hidup pekerja tersebut. Bagi perusahaan, terjadi kerugian produksi akibat waktu yang terbuang pada saat melakukan penyelidikan atas kecelakaan tersebut serta biaya untuk melakukan proses hukum atas kecelakaan kerja.

Kecelakaan tidak mungkin terjadi secara kebetulan sehingga pasti ada sebab dibalik setiap kecelakaan. Penting sekali agar suatu kecelakaan diteliti dan ditemukan penyebabnya sehingga dapat dilakukan usaha untuk mencegah terjadinya kecelakaan tersebut terulang kembali. Pencegahan kecelakaan bertujuan untuk mengurangi peluang terjadinya kecelakaan hingga mutlak minimum, mengurangi bahaya serta risiko yang dihasilkan dalam suatu kegiatan pekerjaan.

Kecelakaan dibagi menjadi 2 jenis, kecelakaan langsung dan kecelakaan tidak langsung. Kecelakaan langsung dapat dibedakan menjadi kejadian kecelakaan sesungguhnya dan juga kejadian nyaris celaka/hampir celaka. Nyaris celaka adalah sebuah kejadian yang hampir menyebabkan terjadinya cedera atau kerusakan dan hanya memiliki selang perbedaan waktu yang sangat singkat. Nyaris celaka tidak mengakibatkan kerusakan, sedangkan kecelakaan pasti mengakibatkan kerusakan.

Sumber bahaya yang ada di rumah sakit harus diidentifikasi dan dinilai untuk menentukan tingkat risiko, yang merupakan tolok ukur kemungkinan terjadinya kecelakaan dan Penyakit Akibat Kerja (PAK). Potensi bahaya di rumah sakit dapat dikelompokkan, dalam tabel berikut ini.

\begin{tabular}{|l|l|}
\hline Bahaya fisik & $\begin{array}{l}\text { Radiasi pengion, radiasi non-pengion, suhu panas, suhu dingin, } \\
\text { bising, getaran, pencahayaan. }\end{array}$ \\
\hline Bahaya kimia & $\begin{array}{l}\text { Ethylene Oxide, formaldehyde, glutaraldehyde, Obat Ca, gas } \\
\text { Anestesi, mercury, chlorine. }\end{array}$ \\
\hline Bahaya biologi & Virus, Hepatitis B, C, HIV, SARS, Bakteri, Jamur dan Parasit. \\
\hline Bahaya ergonomi & Posisi statis, mengangkat, membungkuk, mendorong. \\
\hline Bahaya psikososial & Kerja shift, stres. \\
\hline Bahaya mekanik & $\begin{array}{l}\text { Berasal dari mesin al; terjepit, terpotong, terpukul, tergulung, } \\
\text { tersayat, tertusuk benda tajam. }\end{array}$ \\
\hline Bahaya listrik & $\begin{array}{l}\text { Sengatan listrik, hubungan arus pendek, kebakaran, petir, listrik } \\
\text { statis. }\end{array}$ \\
\hline Limbah rumah sakit & $\begin{array}{l}\text { Limbah medis (jarum suntik, vial obat, nanah, darah), limbah non } \\
\text { medis, limbah cairan tubuh manusia (droplet, liur, sputum). }\end{array}$ \\
\hline
\end{tabular}


Ada beberapa langkah dan strategi pelaksanaan Keselamatan dan Kesehatan Kerja di Rumah Sakit (K3RS), yaitu:

1) Advokasi ke pimpinan RS, sosialisasi dan pembudayaan K3RS.

2) Menyusun kebijakan K3RS yang ditetapkan oleh pimpinan RS.

3) Membentuk Organisasi K3RS.

4) Perencanaan K3 sesuai standar K3RS yang ditetapkan oleh Depkes.

5) Menyusun pedoman dan SOP K3RS diantaranya sebagai berikut.

- pedoman praktis ergonomi di rumah sakit

- pedoman pelaksanaan pelayanan kesehatan kerja

- pedoman pelaksanaan pelayanan keselamatan kerja

- pedoman pelaksanaan penanggulangan kebakaran

- pedoman pelaksanaan tanggap darurat di rumah sakit

- pedoman pengelolaan penyehatan lingkungan rumah sakit

- pedoman pengelolaan faktor risiko di rumah sakit

- pedoman pengelolaan limbah rumah sakit

- pedoman kontrol terhadap penyakit infeksi

- pedoman control terhadap bahan berbahaya dan beracun (B3)

- penyusunan SOP kerja dan peralatan masing-masing unit kerja rumah sakit.

6) Melaksanakan 12 program K3RS yang telah disebutkan sebelumnya

7) Melakukan evaluasi pelaksanaan K3RS.

8) Melakukan internal audit program K3RS dengan menggunakan instrument self assessment akreditasi rumah sakit yang berlaku.

9) Mengikuti Akreditasi rumah sakit.

\section{Penutup}

Kesimpulan dan Saran

Keselamatan dan kesehatan kerja merupakan suatu pemikiran dan upaya untuk menjamin keutuhan dan kesempurnaan baik jasmani maupun rohani dalam usaha mencegah kemungkinan terjadinya kecelakaan dan penyakit akibat kerja. Tujuan keselamatan dan kesehatan kerja di rumah sakit yaitu terciptanya lingkungan kerja yang aman, sehat dan produktif untuk pekerja, aman dan sehat bagi pasien, pengunjung, masyarakat dan lingkungan sekitar rumah sakit sehingga proses pelayanan rumah sakit berjalan baik dan lancar.

Seorang perawat perlu memahami dan menerapkan konsep dasar keselamatan dan kesehatan kerja untuk menghindari terjadinya risiko dan hazard atau bahaya dalam pemberian 
asuhan keperawatan di rumah sakit. Konsep dasar Keselamatan dan Kesehatan Kerja Rumah Sakit (K3RS) adalah upaya terpadu seluruh pekerja rumah sakit, pasien, pengunjung/pengantar orang sakit untuk menciptakan lingkungan kerja, tempat kerja rumah sakit yang sehat, aman dan nyaman baik bagi pekerja rumah sakit, pasien, pengunjung/pengantar orang sakit maupun bagi masyarakat dan lingkungan sekitar rumah sakit.

\section{Daftar Pustaka}

Ardi, S. Z. \& Hariyono, W. (2018). Analisa Penerapan Budaya Perilaku Keselamatan dan Kesehatan Kerja di Rumah Sakit. Jurnal Fakultas Kesehatan Masyarakat, 12(1), 15-20.

Bando, J. J., Kawatu, P. A. T., \& Ratag, B. T. (2020). Gambaran penerapan program Keselamatan dan Kesehatan Kerja Rumah Sakit di RS Advent Manado. Jurnal KESMAS, 9(2), 33-40.

Indragiri, S. (2018). Manajemen risiko K3 menggunakan Hazard Identification Risk Assessment and Risk Control (HIRARC). Jurnal Kesehatan, 9(1), 39-52.

Irzal. (2016). Dasar-dasar kesehatan dan keselamatan kerja. Jakarta: Kencana.

Ismainar, H. (2015). Keselamatan pasien di rumah sakit. Yogyakarta: Deepublish.

Ivana, A., Widjasena, B., \& Jayanti, S. (2014). Analisa Komitmen Manajemen Rumah Sakit (RS) terhadap Keselamatan dan Kesehatan Kerja (K3) pada RS Prima Medika Pemalang. Jurnal Kesehatan Masyarakat (e-Journal), 2(1), 35-41.

Rejeki, S. (2015). Sanitasi hygene dan K3 (Kesehatan \& Keselamatan Kerja). Bandung: Penerbit Rekayasa Sains.

Simamora, R. H. (2011). ROLE CONFLICT OF NURSE RELATIONSHIP WITH PERFORMANCE IN THE EMERGENCY UNIT OF HOSPITALS RSD DR. SOEBANDI JEMBER. The Malaysian Journal of Nursing, 3(2), 23-32.

Sucipto, C. D. (2014). Keselamatan dan Kesehatan Kerja. Yogyakarta: Gosyen Publishing.

Suharto \& Suminar, R. (2016). Hubungan pengetahuan dan sikap perawat dengan tindakan pencegahan infeksi di ruang ICU rumah sakit. Jurnal Riset Hesti Medan, 1(1), 1-9.

Yunita, A. R., Sriatmi, A., \& Fatmasari, E. Y. (2016). Analisis faktor-faktor kebijakan dalam implementasi program keselamatan dan kesehatan kerja rumah sakit di IGD RSUD Kota Semarang. Jurnal Kesehatan Masyarakat (e-Journal), 4(2), 1-9. 